\title{
Stability and Presence of Pesticide Residue Sample Extracts of Soil and Vegetable: Eloor \& Edayar Region, Kerala, Industrial Hub Nearer to Arabian Sea
}

\begin{abstract}
Divya KR ${ }^{1 *}$, Midhun TR ${ }^{3}$, Moushmi KS', Cheriyan AS $^{1}$, Nisari AR ${ }^{1}$, Ratheeshkumar CS $^{4}$, Shaiju P $^{1}$, MartinGD ${ }^{1}$ and Chandramohanakumar $\mathbf{N}^{1,2}$ ${ }^{1}$ Department of Chemical Oceanography, Cochin University of Science and Technology, India ${ }^{2}$ Inter University Centre for Development of Marine Biotechnology, Cochin University of Science and Technology, India

${ }^{3}$ Department of Applied Chemistry, Cochin University of Science and Technology, India

${ }^{4}$ School of Environmental studies, Cochin University of Science and Technology, India

*Corresponding author: Divya KR, Department of Chemical Oceanography, Cochin University of Science and Technology, Cochin, India
\end{abstract}

Received: February 19, 2021; Accepted: March 15, 2021; Published: March 22, 2021

\begin{abstract}
Eloor-Edayar, (latitude $9^{\circ} 3^{\prime} \mathrm{N}$ and $10^{\circ} 6^{\prime} \mathrm{N}$ and longitudes $76^{\circ} 18^{\prime} \mathrm{E}$ and $76^{\circ} 30^{\prime}$ and an area of $14.21 \mathrm{~km}^{2}$ ) the landmass situated on the banks of River Periyar, is known as the industrial backbone of Kerala. The previous reports reveal this region is highly contaminated by heavy metal from industrial effluents. The present study focuses on pesticides in vegetables (Ladies finger, Papaya, Kachil- yam, Guava, Tapioca, Ginger) and related soil extracts when kept in cold conditions and their presence after a long period. The samples collected in May 2008 pre-monsoon, the environment when the soil and vegetables were free from volatile organic components, accelerates the adsorption of pesticides and high temperature. The samples shoot vegetable ladies finger, edible root vegetables Kachil-Yum, Tapioca and Ginger, fruits like Papaya and Guava and the sediments nearer land. The sample extracts analyzed in 2019 after keeping in the cold as well as the usual conditions. The Analysis report shows the pesticides present in the vegetables and soil are $\alpha, \beta, y$ BHC Aldrin, Dicofol, $\alpha, \beta$, Endosulfan, Dieldrin, OPDDT and PPDDT. Aldrin, Dicofol and BHC are the related forms in ladies Finger contains y BHC, $\alpha, \beta$, Endosulfan, Dieldrin, Aldrin, PPDDT. Ginger added $\alpha, \beta$, y BHC Aldrin, Dicofol, $\alpha, \beta$, Endosulfan, OPDDT and PPDDT. Tapioca carried $\alpha, \beta, y$ BHC, Dicofol and PPDDT. Kachil-Yum absorbed $\alpha, \beta, y$ BHC Aldrin, Dicofol, $\alpha, \beta$, Endosulfan, OPDDT and PPDDT. Papaya contains $\alpha$ and y BHC. Guava captivated $\alpha$, y BHC Aldrin, Dicofol, $\alpha$ Dieldrin OPDDT and PPDDT.
\end{abstract}

Keywords: Eloor-edayar; Organochlorine pesticides; Endosulfan; DDT

\section{Introduction}

The "Green Revolution" initiated in the 1960s made India No. 1 manufacturer of pesticides in Asia and $12^{\text {th }}$ globally. Due to uncontrolled use, Indian foods and vegetables have the highest residues in the world. At the national level in India, Kerala is the highest [1] among in districts Kasaragod [2] and Palakkad [3].

Environmental bioaccumulation potential and associated health issues, most of the OCL pesticides categorized as environmental hazards and banned by The Stockholm Convention [4-6]. WHO reports that at present, in Developing countries, organochlorine pesticides used for farming [7] even though Developed countries have declared them as primary pollutants [7-11]. Microorganisms, invertebrates, plants, birds like the peregrine falcon, sparrow hawk and bald eagle, fish and blood plasma of agrifarmers affected badly by OCLs [12-18].

Among Humans, effects of pesticide contamination causes Neuromuscular disorders, stimulation of drug and steroid metabolism $[19,20]$, potential risk factor for gallstone disease [21], vitamin D deficiency [22] and also affects endocrine-disruption activity in patients with neonatal thyroid hormone status. Endosulfan residues in humans bioaccumulated through plants and animal foods and Gastrointestinal absorption of it damages CNS-central nerve system causing acute inhalation toxicity $[23,24]$. Dialdrin is partly responsible for risk increment of Parkinsons disease. Thyroid hormone levels of the newborn are affected by $\beta-\mathrm{HCH}, \mathrm{HCB}$ and DDT residues. Heptachlor bring mitochondria-mediated cell death by spoiling electron transport chain complex III and become neurotoxicant and in patients with Parkinson's disease [25]. In the research on passing from one species to its offspring it seemed Pesticide residue are seen present in eggs of sea birds [26] and humans in Korea, Guerrero, Mexico, China and India transferred via maternal cord sera, blood, and the placenta and breast milk [27].

Chemical compounds that terminate insects, fungi, bacteria, herbs or rodents are generally known as Pesticides. Pesticides are classified based on their nature, application, and targeted pests. By nature, they are organochlorine (DDT, Dieldrin, lindane, Endosulfanetc), organophosphorus (Parathion, Malathion etc.). It is applicable for Agriculture, Public health, and Domestic purposes. It targets pests as insects -insecticide, fungi- fungicide, herbs-herbicide and rodentsrodenticides [28]. At the application of organochlorine pesticide group (DDT, DDD, Dicofol, Eldrin, Dieldrin, Chlorobenziate, Lindane, BHC, Methoxychloro Aldrin, Chlordane, Heptachlor, Endosulfan, Isodrin, Isobenzan, Toxaphene, Chloropropylate) is well known than the rapidly hydrolyzed degradation of the environmental organophosphorous $[29,30]$. Organochlorine pesticides persist for days to years in the environment, Endosulfan $\mathrm{C}_{9} \mathrm{H}_{6} \mathrm{C}_{16} \mathrm{O}_{3} \mathrm{~S}$ has a halflife of 35 ( $\alpha$-isomer) to $150(\beta$-isomer) days, and Dichloro Diphenyl
Austin J Environ Toxicol - Volume 7 Issue 1 - 2021

ISSN: 2472-372X | www.austinpublishinggroup.com

Divya et al. @ All rights are reserved
Citation: Divya KR, Midhun TR, Moushmi KS, Cheriyan AS, Nisari AR, Ratheeshkumar CS, et al. Stability and Presence of Pesticide Residue Sample Extracts of Soil and Vegetable: Eloor \& Edayar Region, Kerala, Industrial Hub Nearer to Arabian Sea. Austin J Environ Toxicol. 2021; 7(1): 1036. 
Trichloroethane (DDT) $\mathrm{C}_{14} \mathrm{H}_{9} \mathrm{C}_{15}$ has a half-life of 2 to 15 years [4,31].

The study region Eloor-Edayar, in Ernakulam district, is the Industrial Area of Kerala and is a hot spot categorized under Green peace [32]. A partial pesticide manufacturing unit, which was closed by Govt due to the local public's protest during the period of sample collection. Many studies conducted here showed that pesticides contaminate the area. A series of pesticide studies from 1990 to 1999 on water and sediment from the Periyar River line was done by the Department of Chemical Oceanography, CUSAT. Menon et al. 2000 [33] studied macro Benthic, Benthic fauna, Prawn, Fish, mollusc and Polychaaetens in this region. Further studies on the survived species were carried out and revised by Martin et al. 2011 [34].

Previous studies focused on the water and sediment samples near estuary or estuarine sediments. The presence of organo phosphorous pesticides Malathion and Methyl Parathion and organo chlorine pesticide Endosulfan samples of Periyar side has been reported by Sujatha et al. 1999 and 1994 [35-37].

This study focused on the baseline data of organochlorine pesticide stability, degradation or pesticide residues in the extracts of vegetables from the land area located at the river end.

\section{Materials and Methods}

\section{Study area}

Eloor is an industrial area-north of Kochi in Ernakulam District in Kerala in India situated between north latitudes $9^{\circ} 3^{\prime}$ and $10^{\circ}$ $6^{\prime}$ and east longitudes $76^{\circ} 18^{\prime}$ and $76^{\circ} 30^{\prime}$. This island has an area of $14.21 \mathrm{~km}^{2}$ formed between two rivers Periyar distributaries and is the largest industrial belt in Kerala. Most of the industries, (70\% approximately 250 companies) of Kerala state in this region, including chemical, engineering, food, drug, paper, rayon, rubber, textiles, and plywood industries. At the time of sample collection in 2008, Eloor, a Panchayat, now turned to Municipality. During the sampling period survey of Department of Industries Govt. of Kerala and Eloor Grama Panchayat had 20 wards of population density $2425 / \mathrm{Km}^{2}$. The panchayat is house to $4.2 \%$ of industrial company workers. The vegetarian and non-vegetarian comprise $3.9 \%$ and $0.1 \%$ of the population. $14.4 \%$ people from Eloor utilized their land for cultivation of food including grains $3.88 \%$, vegetables $1.48 \%$, fruits $1.292 \%$, coconut $16.17 \%$ and roots $0.25 \%$. $95.93 \%$ of water in wells is contaminated. The sampling was during May 2008 Pre Monsoon period (Figure 1 and Table 1).

The soil samples and vegetables were collected and transferred to the laboratory in glass bottles. $\mathrm{pH}$ and Eh of the soil analyzed by Table 1: Sampling site and Sample Description.

\begin{tabular}{|c|c|c|c|}
\hline & Sampling site & Soil colour & Vegetable/Fruit \\
\hline S1 & $\begin{array}{c}\text { Eloor panchayat colony (10.084686N; 76.291281E) near to Panachithodu } \\
(10.08815 N ; 76.290820 \mathrm{E})\end{array}$ & Blackish & Yellow \\
\hline S2 & Kanjirakkuzhi $(10.086123 \mathrm{~N} ; 76.291994 \mathrm{E})$ & Blackish & Kachil-Yam (root vegetables) \\
\hline S3 & Kuzhikkandamthodu (10.04508N; 76.17301E) & $\begin{array}{c}\text { Reddish- } \\
\text { brown }\end{array}$ & - \\
\hline S4 & Periyar, Muttinakamkadavu (10.085290N; 76.283535E) & brown & - \\
\hline S5 & Near Periyar (10.084686N; 76.291281E) & $\begin{array}{c}\text { Slight blackish } \\
\text { Blackish }\end{array}$ & $\begin{array}{c}\text { Tapioca and Ginger (root vegetables), ladies finger (shoot } \\
\text { vegetables) }\end{array}$ \\
\hline S6 & Depot road (Agricultural land) (10.085316N; 76.17201E) & Blackish \\
\hline S7 & Opposite to HIL (10.079591N; 76.301873E) & Papaya (Fruit) \\
\hline
\end{tabular}

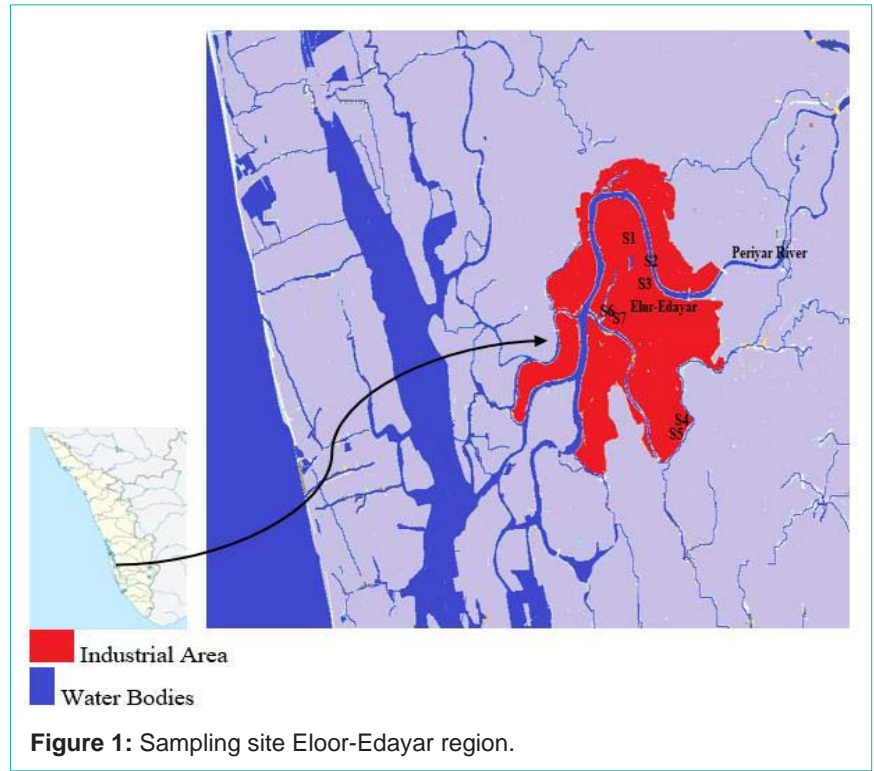

APHA methods [38].

\section{Extraction of pesticides}

About $2 \mathrm{~g}$ wet weight of vegetables or $10 \mathrm{gm}$ soil/sediment was taken in a $250 \mathrm{ml}$ glass-stoppered Erlenmeyer flask and converted to dry weight data. The sample was extracted with $150 \mathrm{ml}$ acetone for $24 \mathrm{~h}$ on a mechanical shaker. The acetone extraction was repeated twice for each sample. The combined supernatant was evaporated to dryness and dissolved into $10 \mathrm{ml}$ hexane. The hexane extract was dried by passing it through a layer of anhydrous sodium sulfate and then concentrated to $2 \mathrm{ml}$ by using a Kuderna-Danish (KD) concentrator. A $2 \mathrm{ml}$ of the $\mathrm{KD}$ extracts of soil/sediment was subjected to Florisil column chromatography (Florisil PR: Floridin Co., 10g) cleanup and fractionation. The Florisil gel was activated at $130^{\circ} \mathrm{C}$ for $12 \mathrm{~h}$, before the fractionation with $120 \mathrm{ml}$ of $100 \%$ hexane and again concentrated to $2 \mathrm{ml}$.

\section{Stability analysis of extract}

The extracts were fractionated with $100 \%$ hexane and concentrates was kept in different temperature from $-20^{\circ} \mathrm{C}$ in a cold stored to room temperature for 10 years (2008 to 2018). It was made up to $2 \mathrm{ml}$ and analyzed for pesticides using GC-ECD. The GC conditions are as follows: injection port temperature $250^{\circ} \mathrm{C}$, detector temperature $350^{\circ} \mathrm{C}$, oven temperature program: $110^{\circ} \mathrm{C}(5 \mathrm{~min})$ at $5^{\circ} \mathrm{Cmin}^{-1}$ to $190^{\circ} \mathrm{C}$ $(2 \mathrm{~min})$ at $15^{\circ} \mathrm{Cmin}^{-1}$ to $280^{\circ} \mathrm{C}(10 \mathrm{~min})$. 


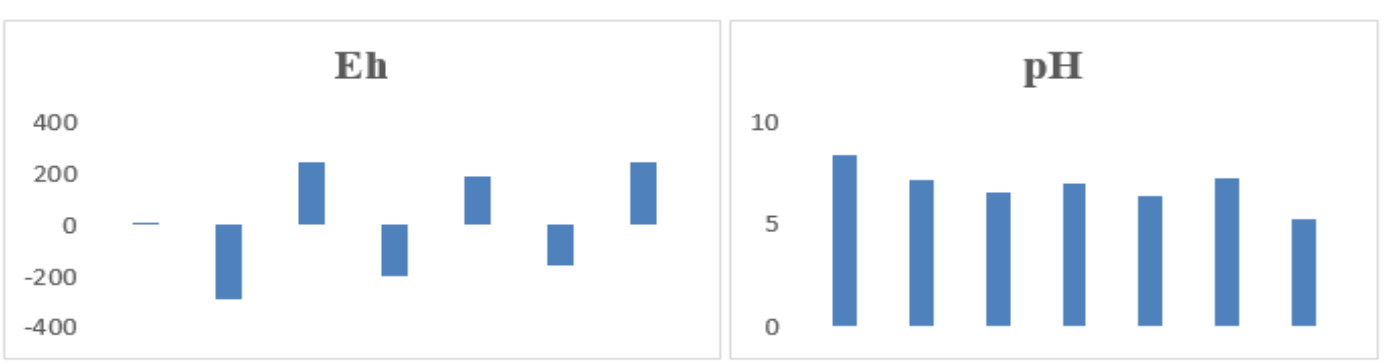

Figure 2: Eh and $\mathrm{pH}$ of the soil samples collected Eloor-Edayar region.

\section{Result and Discussion}

The soil's $\mathrm{pH}$ in this area varied from 5.24 and 8.39 and Eh of soil $-288 \mathrm{mV}$ to $245 \mathrm{mV}$ (Figure 2). $\mathrm{pH}$ and Eh of soils affect plant metabolism and catabolism [39], by influencing nutrient and ion toxicity transport $[40,41]$. The optimum $\mathrm{pH}$ and Eh for plants is 6.5 to $7,+400$ to $+450 \mathrm{mV}$, and favorable conditions for plant growth are between pH 5.5 and 8. Furthermore, Eh greater $+350 \mathrm{mV}$ [42]. The soil samples collected from Kuzhikkandamthodu (Eh -197mV \& pH 7), Panachithodu (Eh -288 mV \& pH 7.15), Muttinakamkadavu (Eh -159mV \& pH 7.29), Eloor Panchayat colony (Eh 0.012mV \& pH 8.39) under the category of highly reduced soils whereas the soils from the area of Depot road (Eh $245 \mathrm{mV} \& \mathrm{pH}$ 5.24) and Kanjirakkuzhi (Eh $242 \mathrm{mV} \& \mathrm{pH} 6.54)$ were found to be moderately reduced. The soil analyzed categorized four types as followed.

Aerated soils over: $>+400 \mathrm{mV}$

Moderately reduced soils: $+100 \mathrm{mV}-+400 \mathrm{mV}$

Reduced soils: $-100 \mathrm{mV}-+100 \mathrm{mV}$

Highly reduced soils: $-100 \mathrm{mV}--300 \mathrm{mV}$ [43]

The study report, Eh indicated the soils in these locations are moderately reduced $[44,45]$, the soil in between approved limits of $-300 \mathrm{mV}$ to $+900 \mathrm{mV}$. 1979, Bressy [46] reported the soil-related stress of $\mathrm{pH}$ and oxidative stress pesticides acts as oxidants. Fewer distances between sampling sites of Eloor Panchayat shows Eh and $\mathrm{pH}$ variations in the soil, which came to an understanding of the other soil scientific reports [42,47].
The residue of $(\alpha, \beta, \gamma)$ BHC, Aldrin, Dicofol, $(\alpha, \beta)$ Endosulfan, Dieldrin OPDDT and PPDDT analyzed as dry basis from Shoot vegetable ladies finger, edible root vegetables Kachil-Yum, Tapioca and Ginger, fruits like Papaya and Guava along with the sediments with different locations (Figure $3 \mathrm{a}$ and $3 \mathrm{~b}$ ).

a, BHC high concentration in soils $689 \mu \mathrm{gm} / \mathrm{gm}$ (Kuzhikkandamthodu) to ND (in Kanjirakkuzhi \& Panachithodu). The root vegetables $112 \mu \mathrm{gm} / \mathrm{gm}$ (Tapioca) and lower in $2 \mu \mathrm{gm} / \mathrm{gm}$ (Ginger).

$\beta$, BHC in the soils $690 \mu \mathrm{gm} / \mathrm{gm}$ (Kuzhikkandamthodu) to ND (Eloorpanjayath colony, Kanjirakkuzhi \& Panachithodu) and only in root vegetables and a high value of $92 \mu \mathrm{gm} / \mathrm{gm}$ (Tapioca).

$\gamma$, BHC detected high $671 \mu \mathrm{gm} / \mathrm{gm}$ (Kuzhikkandamthodu) to ND (Eloor panjayath colony and Kanjirakkuzhi) and the fruits $163 \mu \mathrm{gm} /$ gm (Guava) to ND (Papaya).

Aldrin residues present $676 \mu \mathrm{gm} / \mathrm{gm}$ (Kuzhikkandamthodu) to lowest $17 \mu g m / g m$ (Kanjirakkuzhi) high $78 \mu g m / g m$ in (Guava) to ND (Papaya).

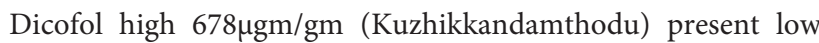
concentration in the soil Eloor panjayath colony and Depot road, vegetables $17 \mu \mathrm{gm} / \mathrm{gm}$ (Guava) present root vegetables tapioca and ginger and ND.

$\alpha$,Endosulfan concentration in $631 \mu \mathrm{gm} / \mathrm{gm}$ (Kuzhikkandamthodu House) and present Kuzhikkandamthodu, Periyar Muttinakamkadavu and Depot road whereas in vegetable $3.8 \times 10^{3} \mu \mathrm{gm} / \mathrm{gm}$ (Tapioca) and

Table 2: Correlation between the decomposition of pesticides in Vegetables and Soil.

\begin{tabular}{|c|c|c|c|c|c|c|c|c|c|c|}
\hline \multirow{2}{*}{ Pesticides in Soil } & \multicolumn{10}{|c|}{ Pesticides in Vegetables } \\
\hline & $\alpha \mathrm{BHC}$ & $\beta, \mathrm{BHC}$ & y BHC & Aldrin & Dicofol & a endosulphan & $\beta$ endosulphan & Dieldrin & OPDDT & PPDDT \\
\hline$\alpha \mathrm{BHC}$ & -0.173 & -0.313 & 0.078 & 0.122 & -0.18 & -0.266 & -0.308 & -0.307 & -0.492 & -0.178 \\
\hline$\beta, \mathrm{BHC}$ & -0.456 & -0.417 & -0.244 & -0.192 & -0.295 & -0.489 & 0.314 & -0.479 & -0.681 & -0.541 \\
\hline Y BHC & -0.398 & -0.446 & -0.196 & -0.128 & -0.28 & -0.462 & 0.17 & -0.394 & -0.697 & -0.534 \\
\hline Aldrin & -0.227 & -0.242 & -0.04 & -0.011 & -0.296 & -0.259 & -0.204 & -0.329 & -0.44 & -0.246 \\
\hline Dicofol & -0.171 & -0.24 & 0.042 & 0.071 & -0.245 & -0.224 & -0.353 & -0.281 & -0.394 & -0.151 \\
\hline$\alpha$ endosulphan & 0.183 & -0.438 & 0.723 & 0.787 & 0.61 & -0.17 & -0.217 & -0.421 & -0.685 & 0.293 \\
\hline$\beta$ endosulphan & 0.368 & -0.275 & $0.863\left(^{*}\right)$ & $0.896\left(^{*}\right)$ & $0.983\left({ }^{* \star}\right)$ & 0.001 & 0.124 & -0.344 & -0.457 & 0.547 \\
\hline Dieldrin & -0.18 & -0.612 & 0.143 & 0.253 & 0.391 & -0.447 & 0.57 & -0.354 & $-0.871\left(^{\star}\right)$ & -0.358 \\
\hline OPDDT & -0.367 & -0.308 & -0.158 & -0.128 & -0.337 & -0.38 & 0.041 & -0.44 & -0.536 & -0.38 \\
\hline PPDDT & -0.037 & -0.421 & 0.421 & 0.475 & 0.219 & -0.271 & -0.264 & -0.444 & -0.65 & 0.06 \\
\hline
\end{tabular}

${ }^{*}$ Correlation is significant at the 0.05 level; ${ }^{* *}$ Correlation is significant at the 0.01 level (2-tailed). 


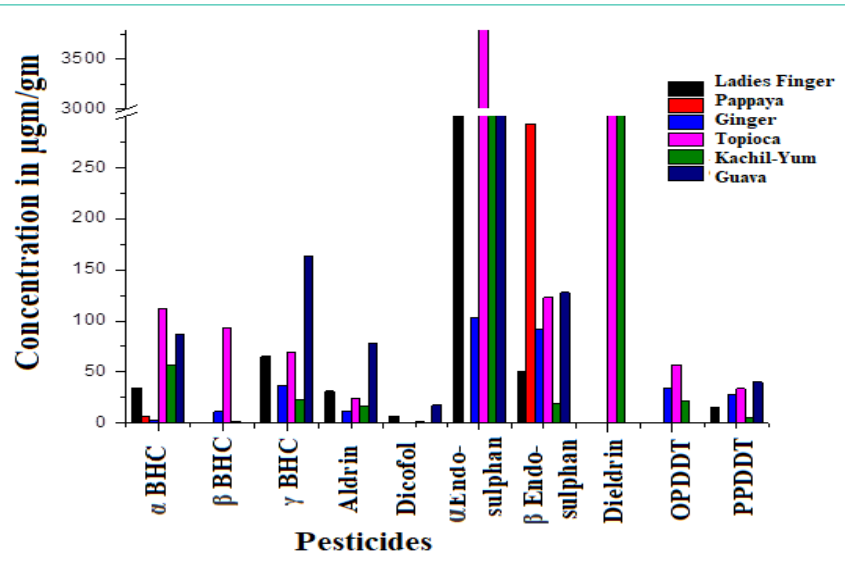

Figure 3a: Concentration of pesticide in vegetables and fruits.

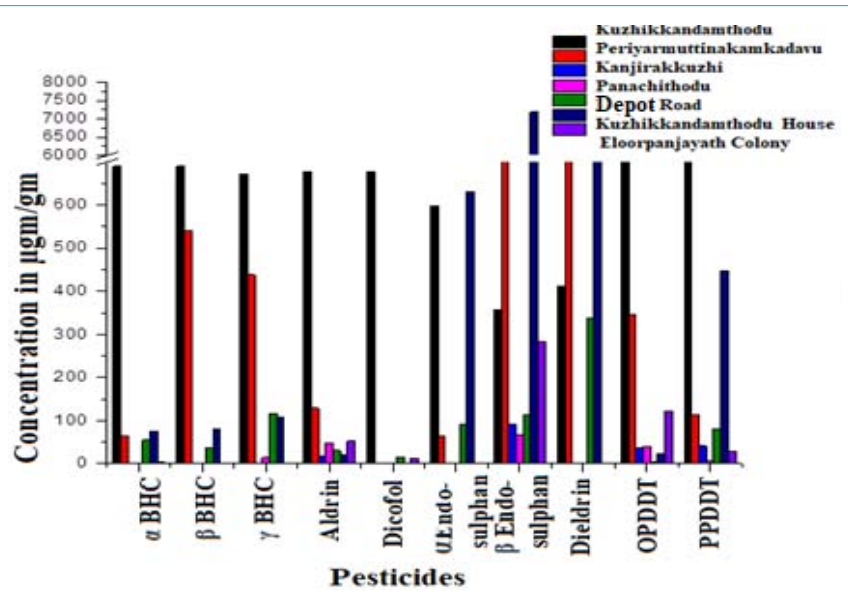

Figure 3b: Concentration of pesticide in the soil samples collected from Eloor-Edayar region.

ND (Papaya).

$\beta$, Endosulfan sensed $861 \mu \mathrm{gm} / \mathrm{gm}$ (Periyar Muttinakamkadavu) ND (Eloor panjayath colony Kanjirakkuzhi \& Panachithodu) and in vegetable $554 \mu \mathrm{gm} / \mathrm{gm}$ (Kachil-Yum) and the other presence in Tapioca.

Dieldrin, the highest concentration of all pesticides $7187 \mu \mathrm{gm} / \mathrm{gm}$

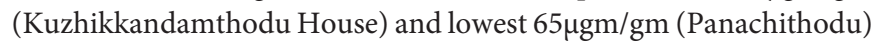
and the fruit $292 \mu \mathrm{gm} / \mathrm{gm}$ (Papaya) to $19 \mu \mathrm{gm} / \mathrm{gm}$ (Kachil-Yum).

OPDDT showed high in $805 \mu \mathrm{gm} / \mathrm{gm}$ (Kuzhikkandamthodu) and lowest $4 \mu \mathrm{gm} / \mathrm{gm}$ (Depot road) and only in root vegetables $554 \mu \mathrm{gm} /$ gm (Tapioca) and $22 \mu \mathrm{gm} / \mathrm{gm}$ (Kachil-Yum).

PPDDT highest in $871 \mu \mathrm{gm} / \mathrm{gm}$ (Kuzhikkandamthodu) and lowest $6 \mu \mathrm{gm} / \mathrm{gm}$ (Panachithodu) contained as $40 \mu \mathrm{gm} / \mathrm{gm}$ (Guava) to ND (Papaya).

The Papaya fruit and root vegetable Ginger had the least presence of pesticides. High metal polluted industrial waste and soil temperature might have led to the decomposition and low residue presence. The water channels which carry industrial effluents and reach the River Periyar, carried these residues. In the seasonal wise studies on DDT in industrial river line area, the pesticide is not observed in the monsoon period36, which revealed the effect of temperature and water runoff.

Correlation between decomposed residues of pesticides in the soil and vegetables is shown in Table 2 . The correlations showed that $\beta$ $\mathrm{BHC}$, OPDDT strong negative, Dialdrin moderate, strong negative and Dicofol week negative. These studies emphasized the earlier monitoring study of pesticide's effect on organism lipid level by Sujatha et al. 1995 [48]. The soil in the Industrial Area is contaminated with organic and inorganic components, which affect the $\mathrm{pH}$ and Eh. Furthermore, Sujatha et al. 1991 [49] studied the equilibrium/ partition model on the fate of pesticides in the soil, which depends on clay materials, hydrous oxides, organic matter, redox stands, $\mathrm{pH}$ of soil system, and climate. This study strongly recommends removing the pesticides from soils of agricultural areas.

\section{Conclusion}

The current study is the Baseline for the pesticide pollutants in the industrial area and their persistence after years in the extraction of sediments and vegetables. The samples collected from the Eloor -Edayar region, the industrial zone of Kerala, indicated significant pesticide levels in the soil and vegetables. The presence of pesticide residues in vegetable extract showed the transport of pollutants from sediment to primary producers, which raises the question of the health of the people lives in that region.

\section{Acknowledgement}

The authors gratefully acknowledge the Dean and Director, School of Marine Sciences, CUSAT for facilities and support. Dr. Salas PM and Dr. Deepulal PM, Department of Chemical Oceanography, CUSAT.

\section{References}

1. Indira Devi P. Pesticide use in the rice bowl of Kerala: Health costs and policy options. SANDEE working paper/South Asian Network for Development and Environmental Economics. 2007.

2. Akhil PS, Sujatha $\mathrm{CH}$. Prevalence of organochlorine pesticide residues in groundwaters of Kasargod District, India. Toxicological \& Environmental Chemistry. 2012; 94: 1718-1725.

3. Gopalan NK, Chenicherry S. Fate and distribution of Organochlorine Insecticides (OCls) in Palakkad soil, India. Sustainable Environment Research. 2018; 28: 179-185.

4. Quijano RF. Endosulfan Poisoning.

5. Mancini F, Van Bruggen AH, Jiggins JL, Ambatipudi AC, Murphy H. Acute pesticide poisoning among female and male cotton growers in India. International journal of occupational and environmental health. 2005; 11: 221-232.

6. Remor AP, Totti CC, Moreira DA, Dutra GP, Heuser VD, Boeira JM. Occupational exposure of farm workers to pesticides: biochemical parameters and evaluation of genotoxicity. Environment international. 2009; 35: 273-278.

7. Townson H. Public health impact of pesticides used in agriculture. Geneva: World Health Organization. 1990: 128.

8. Wesseling C, Aragón A, Castillo L, Corriols M, Chaverri F, Cruz ED, et al. Hazardous pesticides in central America. International journal of occupational and environmental health. 2001; 7: 287-294

9. Konradsen F, van der Hoek W, Cole DC, Hutchinson G, Daisley H, Singh $\mathrm{S}$, et al. Reducing acute poisoning in developing countries-options for restricting the availability of pesticides. Toxicology. 2003; 192: 249-261.

10. Coronado GD, Thompson B, Strong L, Griffith WC, Islas I. Agricultural task and exposure to organophosphate pesticides among farmworkers. 
Environmental health perspectives. 2004; 112: 142-147.

11. Aktar W, Sengupta D, Chowdhury A. Impact of pesticides use in agriculture: their benefits and hazards. Interdisciplinary toxicology. 2009; 2: 1-2.

12. Monirith I, Ueno D, Takahashi S, Nakata H, Sudaryanto A, Subramanian A, et al. Asia-Pacific mussel watch: monitoring contamination of persistent organochlorine compounds in coastal waters of Asian countries. Marine Pollution Bulletin. 2003; 46: 281-300.

13. Liess M, Brown C, Dohmen P, Duquesne S, Heimbach F, Kreuger J, et al. Effects of Pesticides in the Field-EPIF. Brussels. 2005.

14. Grande M, Andersen S, Berge D. Effects of pesticides on fish. Norwegian Journal of Agricultural Sciences. 1994; 13: 195-209.

15. Castillo LE, Martínez E, Ruepert C, Savage C, Gilek M, Pinnock M, et al Water quality and macroinvertebrate community response following pesticide applications in a banana plantation, Limon, Costa Rica. Science of the total environment. 2006; 367: 418-432.

16. DeLorenzo ME, Scott GI, Ross PE. Toxicity of pesticides to aquatic microorganisms: a review. Environmental Toxicology and Chemistry: An International Journal. 2001; 20: 84-98.

17. Frankart C, Eullaffroy P, Vernet G. Comparative effects of four herbicides on non-photochemical fluorescence quenching in Lemna minor. Environmental and Experimental Botany. 2003; 49: 159-168.

18. Mitra A, Chatterjee C, Mandal FB. Synthetic chemical pesticides and their effects on birds. Res J Environ Toxicol. 2011; 5: 81-96.

19. Subramaniam K, Solomon J. Organochlorine pesticides BHC and DDE in human blood in and around Madurai, India. Indian Journal of Clinical Biochemistry. 2006; 21: 169.

20. Forns J, Lertxundi N, Aranbarri A, Murcia M, Gascon M, Martinez D, et al. Prenatal exposure to organochlorine compounds and neuropsychological development up to two years of life. Environment international. 2012; 45: 72 77.

21. Su Y, Dai Y, Lin Y, Gao X, Han Y, Zhao B. Serum organochlorine pesticide residues and risk of gallstone disease: a case-control study in Xiamen. Annals of epidemiology. 2012; 22: 592-597.

22. Yang JH, Lee YM, Bae SG, Jacobs Jr DR, Lee DH. Associations between organochlorine pesticides and vitamin $\mathrm{D}$ deficiency in the US population. PLoS One. 2012; 7: e30093.

23. Briz V, Molina-Molina JM, Sánchez-Redondo S, Fernández MF, Grimalt JO Olea N, et al. Differential estrogenic effects of the persistent organochlorine pesticides dieldrin, endosulfan and lindane in primary neuronal cultures. Toxicological Sciences. 2011; 120: 413-427.

24. USEPA. Endosulfan. The Health Effects Divion's Human Health Risk Assessment. EPA DP Barcode: D372569. 2010.

25. Hong S, Hwang J, Kim JY, Shin KS, Kang SJ. Heptachlor induced nigral dopaminergic neuronal loss and Parkinsonism-like movement deficits in mice. Experimental \& molecular medicine. 2014; 46: e80.

26. Pearce PA, Elliott JE, Peakall DB, Norstrom RJ. Organochlorine contaminants in eggs of seabirds in the Northwest Atlantic, 1968-1984. Environmental Pollution. 1989; 56: 217-235.

27. Li C, Cheng Y, Tang Q, Lin S, Li Y, Hu X, Nian J, Gu H, Lu Y, Tang H, Dai $\mathrm{S}$. The association between prenatal exposure to organochlorine pesticides and thyroid hormone levels in newborns in Yancheng, China. Environmental research. 2014; 129: 47-51

28. Jayaraj R, Megha P, Sreedev P. Organochlorine pesticides, their toxic effects on living organisms and their fate in the environment. Interdisciplinary toxicology. 2016; 9: 90-100

29. Gupta PK. Pesticide exposure-Indian scene. Toxicology. 2004; 198: 83-90.

30. FAO. Proceedings of the Asia Regional Workshop, Regional Office for Asia and the Pacific, Bangkok. 2005.
31. Augustijn-Beckers PW, Hornsby AG, Wauchope RD. The SCS/ARS/ CES pesticide properties database for environmental decision-making II: Additional compounds. Reviews of environmental contamination and toxicology. 1994; 137: 1-82.

32. Kumar R, Joseph MM, Gireesh Kumar TR, Renjith KR, Manju MN, Chandramohanakumar N. Spatial variability and contamination of heavy metals in the inter-tidal systems of a tropical environment. International journal of environmental research. 2010; 4: 691-700.

33. Menon NN, Balchand AN, Menon NR. Hydrobiology of the Cochin backwater system: A review. Hydrobiologia. 2000; 430: 149-183.

34. Martin GD, Nisha PA, Balachandran KK, Madhu NV, Nair M, Shaiju P, et al. Eutrophication induced changes in benthic community structure of a flow-restricted tropical estuary (Cochin backwaters), India. Environmental monitoring and assessment. 2011; 176: 427-438

35. Sujatha $\mathrm{CH}$, Nair SM, Chacko J. Determination and distribution of endosulfan and malathion in an Indian estuary. Water research. 1999; 33: 109-114.

36. Sujatha $\mathrm{CH}$, Nair SM, Kumar NC, Chacko J. Distribution of dichlorodiphenyltrichloroethane (DDT) and its metabolites in an Indian waterway. Environmental Toxicology and Water Quality. 1994; 9: 155-160.

37. Sujatha $\mathrm{CH}$, Nair SM, Chacko J. Sorption of malathion and methylparathion by tropical aquatic sediments: influence of $\mathrm{pH}$. Toxicological \& Environmental Chemistry. 1994; 41: 47-55.

38. American Public Health Association, American Water Works Association Water Pollution Control Federation, Water Environment Federation. Standard methods for the examination of water and wastewater. American Public Health Association. 1912

39. Pasternak TP, Prinsen E, Ayaydin F, Miskolczi P, Potters G, Asard H, et al. The role of auxin, $\mathrm{pH}$, and stress in the activation of embryogenic cell division in leaf protoplast-derived cells of alfalfa. Plant physiology. 2002; 129: 18071819.

40. Brady NC, Weil RR, Brady NC. Elements of the nature and properties of soils. Upper Saddle River, NJ: Pearson educational international. 2010.

41. Marschner H. Mechanisms of adaptation of plants to acid soils. Plant and soil. 1991; 134: 1-20

42. Husson O. Redox potential (Eh) and $\mathrm{pH}$ as drivers of soil/plant/microorganism systems: a transdisciplinary overview pointing to integrative opportunities for agronomy. Plant and Soil. 2013; 362: 389-417.

43. Kaurichev IS, Shishova VS. Oxidation-Reduction Conditions of CoarseTextured Soils of Meshchera Lowland. Soviet Soil Science-Ussr. 1967: 636.

44. Pearsall $\mathrm{WH}$, Mortimer $\mathrm{CH}$. Oxidation-reduction potentials in waterlogged soils, natural waters and muds. The Journal of Ecology. 1939 Aug 1:483-501.

45. Pezeshki SR. Wetland plant responses to soil flooding. Environmental and Experimental Botany. 2001; 46: 299-312.

46. Hinsinger P, Bengough AG, Vetterlein D, Young IM. Rhizosphere: biophysics, biogeochemistry and ecological relevance. Plant and soil. 2009; 321: 117152.

47. Yang J, Hu Y, Bu R. Microscale spatial variability of redox potential in surface soil. Soil science. 2006; 171: 747-753.

48. Sujatha $\mathrm{CH}$, Nair SM, Chacko J. Tissue lipid levels of the clam, Villorita cyprenoides var. cochinensis, following exposure to endosulfan, malathion, and methyl parathion. Environmental Toxicology and Water Quality. 1995; 10: 231-235

49. Sujatha $\mathrm{CH}$, Chacko J. Malathion sorption by sediments from a tropical estuary. Chemosphere. 1991; 23: 167-180. 